\title{
KOMPONEN-KOMPONEN KURIKULUM
}

\author{
Saridudin \\ Puslitbang Pendidikan Agama dan Keagamaan \\ Badan Litbang Dan Diklat Kementerian Agama RI \\ dudinsaridudin@gmail.com
}

\begin{abstract}
A curriculum in a broad sense is defined as a teaching program at an educational level. Whereas in the narrow sense, it is a subject for several hours of lessons. The curriculum design must fulfill two requirements, namely (1) conformity between the curriculum and the demands, needs, conditions, and development of society; (2) compatibility between curriculum components, namely the content according to the objectives, the process according to the content and objectives. The sources of making a curriculum consist of science, society, immortality and divinity, knowledge, and learners. The considerations that underlie the making of a curriculum design are scope, sequence, continuity, integration, articulation, and balance. The curriculum component consists of four elements, namely the objective component, the teaching material component, the strategy component, and the evaluation component.
\end{abstract}

Key words : Curriculum component, objective, material, strategy, evaluation.

\begin{abstract}
Abstrak
Kurikulum dalam arti luas diartikan sebagai program pengajaran pada suatu jenjang pendidikan. Sedangkan dalam arti sempit yaitu suatu mata pelajaran untuk beberapa jam pelajaran. Desain kurikulum harus memenuhi dua syarat yaitu (1) kesesuaian antara kurikulum dengan tuntutan, kebutuhan, kondisi, dan perkembangan masyarakat; (2) kesesuaian antara komponen-komponen kurikulum yaitu isi sesuai dengan tujuan, proses sesuai dengan isi dan tujuan. Sumber-sumber pembuatan sebuah kurikulum terdiri dari ilmu, masyarakat, keabadian dan keilahian, pengetahuan, dan peserta didik. Pertimbangan-pertimbangan yang mendasari pembuatan sebuah desain kurikulum adalah jangkauan (scope), rentetan (sequence), kesinambungan (continuity), integrasi, artikulasi, dan keseimbangan. Komponen kurikulum terdiri dari empat elemen yaitu kompenen tujuan, kompenen materi ajar, komponen strategi, dan komponen evaluasi.
\end{abstract}

Kata kunci : Komponen kurikulum, tujuan, materi, strategi, evaluasi.

\section{A. PENDAHULUAN}

Pendidikan memegang peranan sentral dalam upaya mengembangkan sumber daya manusia. Oleh karena itu, usaha perbaikan terhadap pendidikan pun terus dilakukan. Salah satunya adalah dengan pengembangan kurikulum. Kurikulum menurut Undang-undang Sisdiknas tahun 2003 didefinisikan sebagai seperangkat rencana dan pengaturan mengenai tujuan, isi, dan bahan pelajaran serta cara yang digunakan sebagai pedoman penyelenggaraan kegiatan pembelajaran untuk mencapai tujuan pendidikan tertentu. Dalam usaha perbaikan pendidikan, tidak hanya diterapkannya kurikulum, tetapi juga 
pengembangan-pengembangannya yang tentunya tidak lepas dari faktor-faktor dan aspekaspek yang mempengaruhinya.

Kurikulum merupakan sejumlah tahapan yang didesain untuk siswa dengan petunjuk institusi pendidikan yang isinya berupa proses yang statis ataupun dinamis dan kompetensi yang harus dimiliki. Oleh karena kurikulum pendidikan itu sangat penting, kurikulum harus mempunyai pijakan atau landasan yang kuat sehingga pendidikan itu tidak akan mudah terombang-ambing oleh keadaan zaman. Alasan yang mendasarinya adalah karena yang dipertaruhkanya adalah manusia yang dihasilkan oleh pendidikan itu sendiri.

Kurikulum Tingkat Satuan Pendidikan di Indonesia merupakan kurikulum operasional saat ini yang disusun dan dilaksanakan di masing-masing satuan pendidikan yang berpusat pada potensi, perkembangan, kebutuhan, dan kepentingan peserta didik. Kurikulum disiapkan bagi sebuah bangsa agar masyarakatnya siap berkompetisi di masa depan. Dalam kehidupan yang penuh kompetisi, tuntutan masyarakat terhadap kualitas semakin tinggi. Hal tersebut dikarenakan masyarakat yakin bahwa sekolah mampu menjawab dan mengantisipasi berbagai tantangan masa depan. Dalam konteks ilmiah, beberapa sekolah berupaya menerapkan konsep kurikulum sekolah yang berbeda dengan sekolah lain dalam meningkatkan kualitas pendidikan di sekolahnya masing-masing.

Kurikulum dapat mencakup lingkup yang sangat luas, yaitu sebagai program pengajaran pada suatu jenjang pendidikan, dan dapat pula menyangkut lingkup yang sangat sempit, seperti program pengajaran suatu mata pelajaran untuk beberapa jam pelajaran. Suatu kurikulum harus memiliki kesesuaian atau relevansi yang meliputi dua hal yaitu pertama kesesuaian antara kurikulum dengan tuntutan, kebutuhan, kondisi, dan perkembangan masyarakat. Kedua, kesesuaian antara komponen-komponen kurikulum, yaitu isi sesuai dengan tujuan, proses sesuai dengan isi dan tujuan. Demikian juga dengan program evaluasi harus sesuai dengan proses, isi dan tujuan kurikulum. Tulisan ini menguraikan komponen-komponen kurikulum yang mencakup tujuan, materi ajar, strategi, dan evaluasi dalam kurikulum.

\section{B. PEMBAHASAN}

Sebuah desain kurikulum mengacu pada penamaan perencanaan beberapa komponen atau bagian ataupun elemen-elemen sebuah kurikulum. Yang menjadi bagian didalamnya antara lain: (1) tujuan dan sasaran (aims and objectives); (2) materi mata 
pelajaran (subject matter); (3) metode pengalaman pembelajaran (method and organization); dan (4) Evaluasi (evaluation) (Ornstein, 1988:232).

Pertanyaan yang harus diajukan bagi para pembuat kurikulum adalah, "Apakah struktur umum tentang kurikulum yang dapat saya kembangkan sehingga bagianbagiannya dapat memajukan atau memberi ide-ide secara keseluruhan?" Pertanyaan tersebut tidak hanya bisa dijawab secara praktis di lapangan. Posner dan Rudnitsky menjelaskan bahwa pendekatan sistematik untuk menciptakan kurikulum (curricula) harus juga diproses dengan konteks kerangka teori.

Desain kurikulum terkait dengan sifat dan perencanaan empat komponen dasar. Menurut Harry Giles, "Kata komponen untuk menunjukkan relasi dan cakupan pengalaman pembelajaran berdasarkan metode dan organisasi." Komponen-komponen tersebut memunculkan beberapa pertanyaan refleksi yang harus segera dijawab oleh para pembuat keputusan kurikulum (Ornstein, 1998: 233). Menurut Giles, keempat pertanyaan atas komponen-komponen kurikulum merupakan suatu pertanyaan yang saling terkait, adapun pertanyaannya adalah:

a. Apa yang harus segera dikerjakan?

b. Mata pelajaran apa saja yang harus dimasukkan ke dalam disain kurikulum?

c. Strategi pembelajaran, sumber daya, dan aktivitas apa yang akan diterapkan?

d. Metode dan sarana apa yang akan digunakan untuk menilai hasil dari kurikulum yang digunakan?

Dalam pembuatan sebuah disain kurikulum harus melibatkan isu filsafat dan teoritis serta isu praktis. Ronald Doll menjelaskan bahwa ada kebingungan ketika orang berpikir tentang disain kurikulum dan pembelajaran (instruksional). Ia mencatat bahwa disain kurikulum adalah induk dari disain pembelajaran. Maka, kurikulum adalah rencana total yang mengatur 4 komponen tujuan, isi, pengalaman dan evaluasi. Idealnya, ketika pembuat kurikulum merenungkan sebuah bagian kurikulum mereka harus membuat keputusan disain pembelajaran dalam konteks kurikulum.

Seorang pembuat kurikulum harus mengetahui atau mempunyai pengetahuan tentang orientasi filsafat dan sosial. Jika mereka tidak mempunyai orientasi tersebut, maka disain kurikulum akan terbatas wawasannya dan logikanya kadang membingungkan.

\section{A. Sumber Daya Pembuatan Desain Kurikulum}

a. Ilmu sebagai sumber daya 
Seorang pengembang kurikulum harus menyandarkan pada pengetahuan sebagai sumber untuk mengatur bahwa metode ilmu memberikan makna dalam disain kurikulum. Dalam hal ini disain berdasarkan pada posisi berdiri (stance), pemecahan masalah akan mempunyai posisi yang di atas. Prosedur pemecahan masalah didasarkan pada pengetahuan tentang science dan pengetahuan lain seperti psikologi. Pendidikan harus mempunyai ide ini terkait dengan prosedur pengetahuan dan strategi pemikiran.

b. Masyarakat sebagai sumber daya

Para desainer kurkulum menyetujui masyarakat sebagai sumber untuk pengembangan kurikulum bahwa sekolah merupakan agen masyarakat sehingga skolah harus menyimpulkan kurikulumnya dari analisis situasi social. Pondasi sosial sudah menjadi pondasi kurikulum yang paling penting. John Dewey menjelaskan bahwa pendidik membutuhkan kedekatan dengan kebutuhan masyarakat. Sekolah harus menyadari bahwa mereka tidak terpisah dari budaya yang lebih besar dan komunitas local di mana mereka berada. Sekolah didisain untuk memenuhi kepentingan social di masyarakat. Sekolah juga tidak bisa bersikap masa bodoh dalam membuat disain kurikulum akan keanekaragaman yang ada, khususnya budaya, etnis dan kelas social. Kurikulum bisa dipahami jika kontekstual secara ekonomi, social, dan politik.

c. Sumber Keabadian dan Keilahian

Kehendak Ilahi sebagai faktor dasar dalam disain kurikulum terkait dengan kebenaran sejati dan bahwa elemen kurikulum dinyatakan dalam manusia melalui Kitab Suci atau dokumen religious yang lain. Hal ini merupakan suatu langkah untuk membentuk suatu pribadi yang bermoral dan bermartabat.

d. Pengetahuan sebagai sumber daya

Banyak hal yang harus didiskusikan tentang alam, kondisi, dan konstruksi sosial dan rekonstruksi pengetahuan, tujuan dari kegiatan, dan aturan-aturan.

e. Peserta didik sebagai sumber daya

Orang menyakini bahwa krikulum harus didasarkan pada apa yang kita ketahui terhadap peserta didik: bagaimana mereka belajar, berperilaku, membangkitkan minat, dan mengembangkan nilai hidup. Disinilah pentingnya pemahaman bahwa peserta didik merupakan pribadi yang unik. Kita mengakui bahwa sebagai tujuan kurikulum merupakan emansipasi setiap individu. 


\section{B. Pertimbangan-pertimbangan Dimensi Desain Kurikulum}

Selain beberapa sumber yang bisa dijadikan acuan dalam pembuatan disain kurikulum, seorang ahli kurikulum hendaklah memperhatikan pertimbangan-pertimbangan dimensi disain kurikulum. Pertimbangan tersebut antara lain:

a. Jangkauan (scope)

Pendidik membutuhkan untuk menyapa kedalaman dan keluasan isi yaitu jangkauannya. Bicara skope, kita tidak hanya mengartikan kedalaman dan tingkat isi yang akan diberikan kepada peserta didik, tetapi juga semua variasi dan tipe pengalaman pendidikan yang diciptakan untuk mendukung pembelajaran peserta didik. Skope berbicara tentang kognitif, afektif, dan bidang psikomotorik.

b. Rentetan (sequence)

Ahli kurikulum ditantang agar bisa secara efektif dengan komponen sehingga kurikulum membantu perkembangan pembelajaran komulatif dan berkelanjutan. Ahli harus memutuskan bagaimana isi dan pengalaman akan menjadi sehingga peserta didik mempunyai kesempatan untuk menhubungkan pengertian mereka dalam kurikulum yang diterapkan.

c. Kesinambungan (continuity)

Pendidik menyadari bahwa peserta didik harus meningkatkan keluasan dan kedalaman pengetahuan. Mereka harus mempunyai kesempatan untuk melihat kembali konsep dan ketrampilan sebanyak mungkin.

d. Integrasi (integration)

Mengacu pada hubungan semua tipe pengetahuan dan pengalaman yang ada dalam rencana kurikulum. Integrasi mengijinkan peserta didik untuk mendapatkan persatuan pandangan akan pengetahuan dan kedalaman makna pada setiap mata pelajaran.

e. Artikulasi (articulation)

Mengacu pada interrelasi dari berbagai aspek kurikulum. Relasi bisa vertical ataupu horizontal. Hubungan vertical menggambarkan relasi beberapa aspek dalam rentetan kurikulum terhadap mata pelajaran.; sedangkan horizontal mengacu pada asosiasi antara berbagai elemen yang terjadi secara simultan.

f. Keseimbangan (balance)

Dalam kurikulum yang seimbang, peserta didik mempunyai kesepatan meguasai pengetahuan dan menginternalisasikan dan memanfaatkan secara tepat untukk personal, sosial, dan tujuan intelektual. 


\section{Komponen-Komponen Utama Kurikulum}

Kurikulum merupakan suatu sistem yang memiliki komponen-komponen tertentu yang saling terkait satu sama lain. Kurikulum adalah alat atau media untuk mendidik peserta didik (Saridudin, 2020). Menurut beberapa referensi yang ada, komponen kurikulum dapat dibedakan menjadi 4 empat komponen, yaitu komponen tujuan, komponen materi, komponen strategi, dan komponen evaluasi. Dalam dunia pendidikan, penetapan komponen tujuan, materi, strategi, dan evaluasi secara menyeluruh dan terintegrasi merupakan suatu proses pendidikan yang sangat penting. Alasan yang melatarbelakanginya adalah pendidikan sebagai upaya sadar dan terencana untuk membantu peserta didik mengembangkan dirinya sebagai manusia seutuhnya memang tidak hanya terbatas pada pengembangan intelektualnya saja. Pendidikan juga perlu mengembangkan peserta didik menuju kematangan spiritual, moral, emosional dan sosialnya. Aspek pengetahuan sangat berperan dalam pendidikan, apalagi kalau pengetahuan yang dimaksud bukan hanya pengetahuan tentang alam semesta tetapi juga pengetahuan tentang dirinya sendiri sebagai manusia yang berziarah menuju Tuhan.

\section{Komponen Tujuan}

Komponen tujuan berhubungan dengan arah atau hasil yang diharapkan sehingga segala proses pembelajaran difokuskan untuk mencapai tujuan tersebut. Tujuan kurikulum mengacu ke arah pencapaian tujuan pendidikan nasional. Tujuan tersebut ditetapkan dalam Undang-Undang (UU) No. 2 tahun 1989 tentang Sistem Pendidikan Nasional. Dalam undang-undang tersebut dijelaskan bahwa kurikulum menyediakan kesempatan yang luas bagi peserta didik untuk mengalami proses pendidikan dan pembelajaran untuk mencapai tujuan pendidikan nasional khususnya dan menciptakan sumber daya manusia yang berkualitas umumnya. Adapun Hirarki tujuan pendidikan dan pembelajaran dapat kita lihat sebagai berikut:

a. Tujuan Pendidikan Nasional

Tujuan pendidikan nasional merupakan tujuan pendidikan umum jangka panjang, tujuan ideal pendidikan bangsa Indonesia. Secara makro tujuan pendidikan nasional bertujuan membentuk organisasi pendidikan bersifat otonom sehingga mampu melaksanakan inovasi untuk menuju lembaga yang beretika, menggunakan nalar, sosial yang positif dan Sumber Daya Manusia yang tangguh. Secara mikro pendidikan nasional bertujuan membentuk manusia yang beriman dan bertakwa kepada Tuhan, selanjutnya 
bertanggung jawab dan berbudi pekerti yang luhur. Secara ekplisit Tujuan Pendidikan Nasional dirumuskan dalam Undang-Undang No. 20 tahun 2003, pasal 3, yang berbunyi, "Pendidikan Nasional berfungsi mengembangkan kemampuan dan membentuk watak serta peradaban bangsa yang bermartabat dalam rangka mencerdaskan kehidupan bangsa, bertujuan untuk berkembangnya potensi peserta didik, agar menjadi manusia yang beriman danbertagwa kepada Tuhan Yang Maha Esa, berahklak mulia, sehat, berilmu, cakap, kratif, mandiri, dan menjadi warga Negara yang demokratis serta bertanggung jawab.

\section{b. Tujuan Institusional}

Tujuan institusional yang mengacu pada tujuan institusi (sekolah) merupakan sasaran pendidikan sesuatu lembaga pendidikan. Dengan kata lain, tujuan institusional merupakan tujuan yang harus dicapai oleh setiap lembaga pendidikan. Tujuan institusional merupakan kualifikasi yang harus dimiliki oleh setiap siswa setelah mereka menempuh atau dapat menyelesaikan program di suatu lembaga pendidikan tertentu.

\section{c. Tujuan Kurikuler}

Tujuan kurikuler merupakan tujuan yang ingin dicapai oleh suatu program studi atau oleh setiap bidang studi atau mata pelajaran. Tujuan ini dapat didefinisikan sebagai kualifikasi yang harus dimiliki peserta didik setelah mereka menyelesaikan suatu bidang studi tertentu dalam institusi pendidikan tertentu. Tujuan kurikuler harus dapat mendukung dan diarahkan untuk mencapai tujuan institusional. Tujuan ini tercermin pada isi setiap mata pelajaran yang harus dikuasi oleh peserta didik dalam setiap satuan pendidikan.

\section{d. Tujuan Pembelajaran Instruksional (Tujuan Khusus)}

Tujuan ini lebih diutamakan karena lebih jelas dan mudah pencapaiannya. Dalam tujuan ini, guru mempersiapkan pelajaran, guru menjabarkan tujuan mengajarnya dalam bentuk tujuan-tujuan khusus atau objectives yang bersifat operasional. Tujuan ini dapat memberikan gambaran yang lebih konkrit, dan menekankan pada perilaku siswa.

Tujuan-tujuan mengajar dibedakan menjadi beberapa kategori, sesuai dengan perilaku yang menjadi sasarannya. Menurut Bloom, dengan bukunya Taxonomy of Educational Objectives terbitan 1965, bentuk perilaku sebagai tujuan yang harus dirumuskan dapat digolongkan kedalam 3 domain, yaitu: 
1. Domain Kognitif

Kognitif adalah tujuan pendidikan yang berhubungan dengan kemampuan intelektual seperti mengingat dan memecahkan masalah. Domain kognitif terbagi menjadi 6 tingkatan yaitu; pengetahuan (knowledge), pemahaman (comprehension), penerapan (application), analisa, sintesis dan evaluasi. Pengetahuan merupakan kemampuan mengingat dan kemampuan mengungkapkan kembali iformasi yang sudah dipelajarinya; pemahaman adalah kemampuan memahami suatu obyek atau subyek pembelajaran; penerapan adalah kemampuan untuk menggunakan konsep, prinsip, prosedur pada siauasi tertentu; analisis adalah kemampuan menguraikan stau memecahkan suatu bahan pelajaran ke dalam bagian-bagian atau unsure-unsur serta hubungan antar bagia; sintesis adalah kemampuan untuk menghimpun bagian-bagian ked ala suatu kesleuruhan yang bermakna; dan evaluasi adalah kemampuan membuat penilaian terhadap sesuatu berdasarkan maksud atau kriteria tertentu.

2. Domain Afektif

Afektif berkenaan dengan sikaf, nilai-nilai dan afresiasi. Domain ini memiliki tingkatan, yaitu; penerimaan, merespon, menghargai, mengorganisasi dan karakterisasi nilai. Penerimaan adalah sikap kesadaran atau kepekaan seseorang terhadap gejala, kodisi, keadaan atau suatu masalah; merespon ditunjukkan oleh kemampuan untuk berpartisipasi aktif dalam kegiatan tertentu seperti kemauan untuk menyelesaikan tugas tepat waktu, kemauan untk mengikuti diskusi, dan kemauan untuk membantu orang lain; menghargai adalah kemampuan untuk member penilaian atau kepercayaan kepada gejala atau suatu obyek tertentu; mengorganisasi, berkenaan dengan pengembangan nilai ke dalam sistem organisasi tertentu, termasuk hubungan antar nilai dan tingkat prioritas nilai-nilai tersebut; karakterisasi nilai adalah kemampuan mengaakan sintesis dan internalisasi sistem nilai dengan pengkajian secara mendalam sehingga nilai-nilai yang dibangunnya dijadikan falsafah hidup serta dijadikan pedoman dalam berperilaku.

\section{Domain Psikomotor}

Psikomotor adalah tujuan yang berhubungan dengan kemampuan keterampilan atau skill seseorang. Tingkatan domain psikomotor yaitu; persepsi (perception), kesiapan (set), meniru (imitation), membiasakan (habitual), menyesuaikan (adaption) dan menciptakan (organization). Persepsi merupakan kemampuan seseorang dalam memandang sesuatu yang dipermasalahkan; kesiapan adalah kesediaan seseorang untuk 
melatih diri tentang ketrampilan tertentu yang direfleksikan dengan perilaku khusus; meniru merupakan kemampuan seseorang dalam mempraktikkan gerakan-gerakan sesuai dengan contoh yang diamati; membiasakan adalah kemampuan seseorang untuk mempraktikka gerakan-gerakan tertentu tanpa harus melihat contoh; menyesuaikan adalah kemampuan untuk menyesuaikan diri dengan keadaan tertetu; dan kemampuan menciptakan tergambar dari kemampuannya menghasilkan sesuatu yang baru.

\section{Komponen Materi Ajar (Bahan Ajar)}

Materi kurikulum pada hakekatnya adalah isi kurikulum yang dikembangkan dan disusun dengan prinsip-prinsip sebagai berikut:

a. Materi kurikulum berupa bahan pelajaran terdiri dari bahan kajian atau topik-topik pelajaran yang dapat dikaji oleh siswa dalam proses pembelajaran.

b. Mengacu pada pencapaian tujuan setiap satuan pelajaran.

c. Materi atau aktivitas yang dilakukan seluruhnya diarahkan untuk mencapai tujuan yang hendak dicapai. Dalam lingkup yang lebih luas yaitu untuk mencapai tujuan pendidikan nasional.

Pada hakikatnya, isi / materi kurikulum adalah semua kegiatan dan pengalaman yang dikembangkan dan disusun untuk mencapai tujuan pendidikan. Secara umum isi kurikulum itu dapat dikelompokan menjadi:

a. Logika, yaitu pengetahuan tentang benar salah berdasarkan prosedur keilmuan.

b. Etika, yaitu pengetahuan tentang baik buruk, nilai dan moral.

c. Estetika, pengetahuan tentang indah-jelek, yang ada nilai seninya.

Kita menyadari bahwa kurikulum merupakan sesuatu yang bersifat dinamis. Artinya, disain kurikulum yang sudah ditetapkan dan diterapkan harus selalu dikaji agar relevan dengan perkembangan peserta didik dan kebutuhan jaman. Pengembangan materi kurikulum harus berdasarkan prinsip-prinsip sebagai berikut:

a. Mengandung bahan kajian yang dapat dipelajari siswa dalam pembelajaran.

b. Berorientasi pada tujuan, sesuai dengan hirarki tujuan pendidikan.

Materi kurikulum mengandung aspek tertentu sesuai dengan tingkat tujuan kurikulum, yang meliputi teori, konsep, generalisasi, prinsip, prosedur, fakta, istilah, contoh atau ilustrasi, definisi, dan preposisi. Kriteria untuk memilih isi materi kurikulum yang relevan harus memenuhi beberapa hal, antara lain: (Taba, 1962: 267)

a. Materi harus sahih dan signifikan, artinya menggambarkan pengetahuan mutakhir. 
b. Relevan dengan kenyataan sosial dan kultur agar anak lebih memahaminya.

c. Materi harus seimbang antara keluasan dan kedalaman.

d. Materi harus mencakup berbagai ragam tujuan.

e. Sesuai dengan kemampuan dan pengalaman peserta didik.

f. Materi harus sesuai kebutuhan dan minat peserta didik.

\section{Komponen Metode, Strategi dan Model Pembelajaran}

Komponen strategi merupakan komponen yang memiliki peran yang sangat penting, sebab berhubungan dengan implementasi kurikulum. Beberapa istilah yang perlu difahami berkaitan dengan komponen ini adalah pendekatan, strategi, model dan metode dalam pembelajaran.

\section{a. Pendekatan Pembelajaran}

Pendekatan pembelajaran adalah suatu upaya menghampiri makna pembelajaran melalui suatu cara pandang tertentu; atau aplikasi suatu cara pandang dan pandangan tertentu dalam memahami makna pembelajaran. Berbagai pendekatan dalam rangka memahami makna pembelajaran antara lain: pendekatan filsafati, pendekatan psikologi dan pendekatan sistem.

Pendekatan filsafati berkaitan dengan bebrapa aliran filsafat pendidikan seperti idealisme, realisme, pragmatisme, eksistensialisme, dan konstruktivisme. Pendekatan psikologi berkaitan dengan beberapa aliran dalam psikologi diantaranya behaviorisme, psikologi kognitif dan humanisme. Pendekatan sistem memandang belajar sebagai suatu keseluruhan terpadu yang terdiri atas berbagai komponen yang saling berinteraksi secara fungsional dalam rangka mencapai tujuan yang telah ditetapkan.

Berbagai aliran baik dalam filsafat maupun psikologi memiliki cara pandang yang berbeda dalam pembelajaran. Dalam pembelajaran idealisme menghendaki diaplikasikannya strategi penemuan (discovery) melalui tanya jawab (dialektika) dan berpikir deduktif. Sekalipun pembelajaran berpusat pada guru, tetapi dalam mengolah pesan siswa harus menemukan sendiri (heuristik). Kurikulum pendidikan idealisme diorganisasi menurut mata pelajaran dan berpusat pada bahan ajar (subject matter centered), sehingga pelajaran bersifat pragmentaris, bahan ajar dipelajari secara terpisah menurut mata pelajaran.

Realisme menghendaki pelajaran dan pengelolaan kelas yang berpusat pada guru (classroom is teacher-centered). Siswa diharapkan belajar dari pengalaman (langsung 
maupun tidak langsung) melalui strategi inquiry, discovery, pembiasaan dan berpikir induktif. Pragmatisme menghendaki pembelajaran yang berpusat pada siswa ( $p u p i l / c h i l d-$ centered), berpusat pada masalah, berpusat pada aktivitas dan bersifat interdisipliner atau terpadu. Pragmatisme menyarankan pembelajaran melalui problem solving, discovery dan inkuiri serta strategi heuristik dan mengutamakan strategi berpikr deduktif-induktif.

Konstruktivisme memandang pembelajaran sebagai suatu kegiatan yang memungkinkan siswa membangun pengetahuannya sendiri. Pembelajaran bukanlah kegiatan guru mentrasfer pengetahuan kepada siswa. Konstruktivisme menghendaki pembelajaran yang berpusat pada siswa, berpusat pada masalah, berpusat pada aktivitas, bersifat interdisipliner (terpadu) dan kontekstual. Eksistensialisme memandang bahwa pembelajaran adalah kegiatan guru mendampingi siswa (belajar) berdasarkan minat bakat dan kebutuhan-kebutuhannya untuk sampai pada penyadaran diri dan mengembangkan komitmen yang berhasil mengenai sesuatu yang penting dan bermakna bagi eksistensinya.

Behaviorisme memandang bahwa pembelajaran adalah kegiatan guru menciptakan kondisi lingkungan sebagai stimulus-berupa tugas, disiplin dan sebagainya-untuk direspon oleh siswa yang dilakukan dalam bentuk pembiasaan atau latihan tahap demi tahap secara rinci yang diikuti dengan penguatan (reinforcement) secara terus menerus, agar terjadi modifikasi tingkah laku (behavior modification) sehingga siswa menguasai kemampuan melakukan sesuatu.

Roy Killen dalam Wina Sanjaya (2011) mengatakan ada dua pendekatan dalam pembelajaran, yaitu pendekatan yang berpusat pada guru (teacher centered approaches) dan pendekatan yang berpusat pada siswa (student centered approach). Pendekatan yang berpusat pada guru menurunkan strategi pembelajran langsung (direct instruction), pembelajaran deduktif atau pembelajaran ekspositori; sedangkan pendekatan pembelajaran yang berpusat pada siswa menurunkan strategi pembelajaran discovery dan inkuiri serta strategi pembelajaran induktif.

Dilihat dari kemasan materi dan cara siswa mempelajari materi Rowntree (1974), straregi pembelajaran dibagi atas: strategi Exposition dan Strategi Discovery Learning serta Strategi Groups dan Individual Learning. Dalam exposition, bahan ajar sudah dikemas sedemikan rupa sehingga siswa tinggal menguasai saja. Strategi ini lebih bersifat strategi yang berorientasi pada penguasaan isi pelajaran (content oriented). Dalam discovery learning, bahan ajar tidak dikemas dalam bentuk yang sudah jadi, tapi siswa diharapkan dapat beraktivitas secara penuh, mencari dan mengumpulkan informasi, 
membandingkan, menganalisis dan sebaginya. Metode yang banyak digunakan adalah pemecahan masalah. Strategi kelompok adalah apabila siswa belajar secara kelompok bersama-sama, mempelajari bahan yang sama, oleh guru yang sama tanpa memperhatikan perbedaan bakat, minat dan kemampuan yang dimiliki. Sedangkan pembelajaran individual adalah manakala pembelajaran memperhatikan kemampuan dasar siswa, kecepatan belajar dan minat yang dimiliki.

\section{b. Strategi Pembelajaran}

Strategi pembelajaran adalah pola umum rencana interaksi antara siswa, guru, dan sumber belajar lainnya pada suatu lingkungan belajar untuk mencapai tujuan pendidikan tertentu.

1. Berdasarkan Rasio Guru dan Siswa dalam Pembelajaran

a. Pembelajaran oleh seorang guru terhadap sekelompok besar (satu kelas) siswa

b. Pembelajaran oleh seorang guru terhadap sekelompok kecil (5-7 orang) siswa

c. Pembelajaran oleh seorang guru terhadap seorang siswa

d. Pembelajaran oleh satu tim guru terhadap sekelompok besar (satu kelas) siswa

e. Pembelajaran oleh satu tim guru terhadap sekelompok kecil (5-7 orang) siswa

2. Berdasarkan Pola Hubungan Guru dan Siswa dalam Pembelajran

a. Pembelajaran tatap muka

b. Pembelajaran melalui media

c. Pembelajaran tatap muka plus melalui media

3. Berdasarkan Peranan Guru dan Siswa dalam Pengelolaan Pembelajaran
a. Pembelajaran yang berpusat pada guru
b. Pembelajarn yang berpusat pada siswa

4. Berdasarkan Peranan Guru dan Siswa dalam mengolah pesan atau Materi Pembelajaran

a. Pembelajaran ekspositorik

b. Pembelajaran heuristik

5. Berdasarkan Proses Berpikir dalam Mengolah Pesan atau Materi Pelajaran
a. Pembelajaran deduktif
b. Pembelajaran induktif
c. Pembelajaran deduktif-induktif 


\section{c. Model Pembelajaran}

Model pembelajaran adalah suatu rencana atau pola yang dapat kita gunakan untuk merancang pembelajaran tatap muka di dalam kelas atau dalam latar tutorial dan dalam membentuk materi-materi pembelajaran-termasuk buku-buku, film-film, pita kaset dan program media komputer, dan kurikulum. Banyak model pembelajaran yang bisa dikembangkan diantaranya pembelajaran kontekstual, pembelajaran kooperatif, pembelajaran inkuiri, pembelajaran model PAKEM, pemodelan dan pembelajaran afektif (Saridudin, 2021). Beberapa model tersebut dijelaskan di bawah ini :

1. Model interaksi sosial

Model Interaksi sosial mencakup strategi pembelajaran/metode pembelajaran:
a. Kerja Kelompok
b. Pertemuan Kelas
c. Pemecahan masalah sosial atau Inquiry Social
d. Model Laboratorium
e. Bermain Peranan
f. Simulasi Sosial

2. Model Pemrosesan Informasi. Strategi/Model pembelajarannya:
a. Mengajar Induktif
b. Latihan inquiry
c. Inquiry Keilmuan
d. Pembentukan Konsep
e. Model pengembangan

3. Model Personal (Personal Model)

Model ini bertitik tolak dari teori Humanistik, yaitu berorientasi kepada pengembangan diri individu. Perhatian utamanya pada emosional siswa untuk mengembangkan hubungan yang produktif dengan lingkungannya. Model pembelajaran personal ini meliputi strategi pembelajaran/metode:
a. Pembelajaran Non-direktif
b. Latihan kesadaran
c. Sinetik
d. Sistem konseptual

4. Model Modifikasi Tingkah Laku 
Model ini bertitik tolak dari teori behavioristik, yaitu bertujuan mengembangkan sistem yang efisien untuk mengurutkan tugas-tugas belajar dan membentuk Tingkah Laku dengan cara memanipulasi penguatan (reinforcement). Model ini lebih menekankan pada aspek perubahan perilaku psikologis dan perilaku yang tidak dapat diamati. Implementasi dari model ini adalah meningkatkan ketelitian pengucapan pada anak, guru selalu perhatian terhadap Tingkah Laku belajar siswa, modifikasi Tingkah Laku anak yang kemampuan belajarnya rendah dengan reward, sebagai reinforcement pendukung, dan penerapan prinsip pembelajaran individual terhadap pembelajaran klasikal.

5. Model Pembelajaran Kontekstual (CTL)

Inti dari pendekatan CTL adalah keterkaitan setiap materi atau topik pembelajaran dengan kehidupan nyata. Mengajar bukan transformasi pengetahuan dari guru kepada siswa dengan menghafal sejumlah konsep-konsep, tetapi lebih ditekankan pada upaya memfasilitasi siswa untuk mencari kemmapuan untuk bisa hidup (life skill) dari apa yang dipelajarinya. Dalam Pembelajaran Kontekstual ada tujuh prinsip pembelajaran yang harus dikembangkan guru yaitu: 1) Konstruktivisme, 2) Menemukan (Inquiry), 3) Bertanya, 4) Masyarakat belajar, 5) Pemodelan, 6) Refleksi, 7) Penilain sebenarnya.

1. Konstruktivisme

Konstruktivisme merupakan landasan berfikir (filosofi) dalam pendekatan CTL, yaitu bahwa pengetahuan dibangun oleh manusia sedikit demi sedikit yang hasilnya diperluas melalui konteks yang terbatas. Pengetahuan bukanlah seperangkat faktafakta, konsep atau kaidah yang siap untuk diambil dan diingat. Manusia harus membangun pengetahuan itu memberi makna melalui pengalaman yang nyata.

2. Menemukan (inquiry)

Menemukan merupakan kegiatan inti dari CTL. Melalui upaya menemukan akan memberikan penegasan bahwa pengetahuan dan keterampilan serta kemampuankemampuan lain yang diperlukan bukan merupakan hasil dari mengingat seperangkat fakta-fakta, tetapi merupakan hasil menemukan sendiri

3. Bertanya (Questioning)

Penerapan unsur bertanya dalam pendekatan CTL harus difasilitasi oleh guru, kebiasaan siswa untuk bertanya atau kemampuan guru dalam menggunakan pertanyaan yang baik akan mendorong pada peningkatan kualitas dan produktivitas pembelajaran. 


\section{Masyarakat Belajar (Learning Community)}

Maksud dari masyarakat belajar adalah membiasakan siswa untuk melakukan kerjasama dan memanafaatkan sumber belajar dari teman-teman belajarnya. Seperti yang disarankan dalam learning community, bahwa hasil pembelajaran diperoleh dari kerjasama dengan orang lain melalui berbagai pengalaman (sharing).

5. Pemodelan (Modeling)

Pembuatan model dapat dijadikan alternatif untuk mengembangkan pembelajaran agar siswa bisa memenuhi harapan siswa secara menyeluruh, dan membantu mengatasi keterbatasan yang dimiliki oleh para guru.

6. Refleksi (Reflection)

Refleksi adalah cara berpikir tentang apa yang baru terjadi atau baru saja dipelajari.

Dengan kata lain refleksi adalah berpikir ke belakang tentang apa-apa yang sudah dilakukan dimasa lalu. Siswa mengedepankan apa yang baru dipelajarinya sebagai struktur pengetahuan yang baru, yang merupakan pengayaan atau revisi dari pengetahuan sebelumnya.

\section{Penilaian Sebenarnya (Authentic Assessment)}

Penilaian adalah proses pengumpulan berbagai data dan informasi yang bisa memberikan gambaran atau petunjuk terhadap pengalaman belajar siswa. Guru akan mengetahui kemajuan, kemunduran dan kesulitan siswa dalam belajar. Dan dengan itu pula guru akan memiliki kemudahan untuk melakukan upaya-upaya perbaikan dan penyempurnaan proses bimbingan belajar dalam langkah selanjutnya.

\section{Komponen Evaluasi}

Evaluasi merupakan salah satu komponen kurikulum untuk melihat efektifitas pencapaian tujuan. Dalam konteks kurikulum, evaluasi dapat berfungsi untuk mengetahui apakah tujuan yang telah ditetapkan telah tercapai atau belum. Evaluasi juga digunakan sebagai umpan balik dalam perbaikan strategi yang ditetapkan. Dengan evaluasi dapat diperoleh informasi yang akurat tentang penyelenggaraan pembelajaran, keberhasilah siswa, guru dan proses pembelajaran. Berdasarkan hasil evaluasi dapat dibuat keputusan kurikulum itu sendiri, pembelajaran, kesulitan dan upaya bimbingan yang diperlukan. Evaluasi kurikulum merupakan tahap akhir dari proses pengembangan kurikulum (Saridudin, 2020). 
Dalam pengertian terbatas, evaluasi kurikulum dimaksudkan untuk memeriksa tingkat ketercapaian tujuan-tujuan pendidikan yang ingin diwujudkan melalui kurikulum yang bersangkutan. Wright mengungkapkan bahwa: "curriculum evaluation may be defined as the estimation of growth and progress of students toward objectives or values of the curriculum". Dalam arti yang lebih luas, evaluasi kurikulum dimaksudkan untuk memperbaiki substansi kurikulum, prosedur implementasi, metode instruksional, serta pengaruhnya pada belajar dan prilaku peserta didik (Hamalik, 2008: 191)

Luas atau tidaknya suatu program evaluasi kurikulum sebenarnya ditentukan oleh tujuan diadakannya evaluasi kurikulum. Apakah evaluasi tersebut ditujukan untuk mengevaluasi keseluruhan sistem kurikulum atau komponen-komponen tertentu saja dalam sistem kurikulum tersebut. Salah satu komponen kurikulum penting yang perlu dievaluasi adalah berkenaan dengan proses dan hasil belajar siswa. Dalam bukunya, Hamalik (2008: 191) menambahkan bahwa evaluasi adalah suatu proses interaksi, deskripsi, dan pertimbangan (judgement) untuk menemukan hakikat dan nilai dari suatu hal yang dievaluasi, dalam hal ini kurikulum.

Pengembangan kurikulum merupakan proses yang tak pernah berakhir (Oliva, 1988). Proses tersebut meliputi perencanaan, implementasi, dan evaluasi. Merujuk pada pendapat tersebut, maka evaluasi merupakan bagian yang tidak dapat dipisahkan dalam pengembangan kurikulum. Melalui evaluasi dapat ditentukan nilai dan arti kurikulum, sehingga dapat dijadikan bahan pertimbangan apakah suatu kurikulum perlu dipertahankan atau tidak, dan bagian-bagian mana yang harus disempurnakan.

Dari beberapa pendapat di atas, kita dapat menyimpulkan bahwa evaluasi kurikulum harus mencakup:

1. Menilai pencapaian tujuan kurikulum yang sudah ditetapkan sebelumnya.

2. Bagaimana metode yang digunakan dalam kurikulum itu efektif atau tidak sehingga bisa mempermudah ketercapaian tujuan.

3. Melihat pengaruh kurikulum itu pada prestasi dan sikap peserta didik, apakah kemajuan dan perkembangan mereka baik atau buruk.

Agar hasil evaluasi kurikulum tetap bermakna diperlukan persyaratan-persyaratan dan prinsip-prinsip evaluasi kurikulum. Dengan mengutip pemikian Doll, dikemukakan syarat-syarat evaluasi kurikulum yaitu "acknowledge presence of value and valuing, orientation to goals, comprehensiveness, continuity, diagnostics worth and validity and 
integration." Adapun prinsip-prinsip evaluasi kurikulum, sebagaimana dikemukakan oleh Oemar Hamalik (2008: 255-256) sebagai berikut:

1. Tujuan tertentu, artinya setiap program evaluasi kurikulum terarah dalam mencapai tujuan yang telah ditentukan secara jelas dan spesifik. Tujuan-tujuan itu pula yang mengarahkan berbagai kegiatan dalam proses pelaksanaan evaluasi kurikulum.

2. Bersifat obyektif, dalam artian berpijak pada keadaan yang sebenarnya, bersumber dari data yang nyata dan akurat, yang diperoleh melalui instrumen yang andal.

3. Bersifat komprehensif, mencakup semua dimensi atau aspek yang terdapat dalam ruang lingkup kurikulum. Seluruh komponen kurikulum harus mendapat perhatian dan pertimbangan secara seksama sebelum dilakukan pengambilan keputusan.

4. Kooperatif dan bertanggung jawab dalam perencanaan. Pelaksanaan dan keberhasilan suatu program evaluasi kurikulum merupakan tanggung jawab bersama pihakpihak yang terlibat dalam proses pendidikan seperti guru, kepala sekolah, pengawas, orang tua, bahkan siswa itu sendiri, di samping merupakan tanggung jawab utama lembaga penelitian dan pengembangan.

5. Efisien, khususnya dalam penggunaan waktu, biaya, tenaga, dan peralatan yang menjadi unsur penunjang. Oleh karena itu, harus diupayakan agar hasil evaluasi lebih tinggi, atau paling tidak berimbang dengan materiil yang digunakan.

6. Berkesinambungan. Hal ini diperlukan mengingat tuntutan dari dalam dan luar sekolah, yang meminta diadakannya perbaikan kurikulum. Untuk itu, peran guru dan kepala sekolah sangatlah penting, karena mereka yang paling mengetahui pelaksanaan, permasalahan, dan keberhasilan kurikulum.

Evaluasi kurikulum juga bervariasi, bergantung pada dimensi-dimensi yang menjadi fokus evaluasi. Salah satu dimensi yang sering mendapat sorotan adalah dimensi kuantitas dan kualitas. Instrumen yang digunakan untuk mengevaluasi dimensi kuantitatif berbeda dengan dimensi kualitatif. Instrumen yang digunakan untuk mengevaluasi dimensi kuantitatif, seperti tes standar, tes prestasi belajar, tes diagnostik dan lain-lain. Sedangkan, instrumen untuk mengevaluasi dimensi kualitatif dapat digunakan, questionnare, observasi, interview, studi kasus, skala penilaian dan sebagainya

Evaluasi kurikulum memegang peranan penting, baik untuk penentuan kebijakan pendidikan pada umumnya maupun untuk pengambilan keputusan dalam kurikulum itu sendiri. Hasil-hasil evaluasi kurikulum dapat digunakan oleh para pemegang kebijakan pendidikan dan para pengembang kurikulum dalam memilih dan menetapkan kebijakan 
pengembangan sistem pendidikan dan pengembangan model kurikulum yang digunakan. Hasil-hasil evaluasi kurikulum juga dapat digunakan oleh guru-guru, kepala sekolah dan para pelaksana pendidikan lainnya dalam memahami dan membantu perkembangan peserta didik, memilih bahan pelajaran, memilih metode dan alat-alat bantu pelajaran, cara penilaian serta fasilitas pendidikan lainnya. (disarikan dari Nana Syaodih Sukmadinata, 1997). Selanjutnya, Nana Syaodih Sukmadinata (1997) mengemukakan tiga pendekatan dalam evaluasi kurikulum, yaitu: (1) pendekatan penelitian (analisis komparatif); (2) pendekatan obyektif; dan (3) pendekatan campuran multivariasi.

Di samping itu, terdapat beberapa model evaluasi kurikulum, diantaranya adalah Model CIPP (Context, Input, Process dan Product) yang bertitik tolak pada pandangan bahwa keberhasilan progran pendidikan dipengaruhi oleh berbagai faktor, seperti: karakteristik peserta didik dan lingkungan, tujuan program dan peralatan yang digunakan, prosedur dan mekanisme pelaksanaan program itu sendiri. Evaluasi model ini bermaksud membandingkan kinerja (performance) dari berbagai dimensi program dengan sejumlah kriteria tertentu, untuk akhirnya sampai pada deskripsi dan judgment mengenai kekuatan dan kelemahan program yang dievaluasi. Model ini kembangkan oleh Stufflebeam (1972) menggolongkan program pendidikan atas empat dimensi, yaitu : Context, Input, Process dan Product. Menurut model ini keempat dimensi program tersebut perlu dievaluasi sebelum, selama dan sesudah program pendidikan dikembangkan. Penjelasan singkat dari keempat dimensi tersebut adalah, sebagai berikut:

1. Context; yaitu situasi atau latar belakang yang mempengaruhi jenis-jenis tujuan dan strategi pendidikan yang akan dikembangkan dalam program yang bersangkutan, seperti: kebijakan departemen atau unit kerja yang bersangkutan, sasaran yang ingin dicapai oleh unit kerja dalam kurun waktu tertentu, masalah ketenagaan yang dihadapi dalam unit kerja yang bersangkutan, dan sebagainya.

2. Input; bahan, peralatan, fasilitas yang disiapkan untuk keperluan pendidikan, seperti : dokumen kurikulum, dan materi pembelajaran yang dikembangkan, staf pengajar, sarana dan pra sarana, media pendidikan yang digunakan dan sebagainya.

3. Process; pelaksanaan nyata dari program pendidikan tersebut, meliputi: pelaksanaan proses belajar mengajar, pelaksanaan evaluasi yang dilakukan oleh para pengajar, penglolaan program, dan lain-lain.

4. Product; keseluruhan hasil yang dicapai oleh program pendidikan, mencakup: jangka pendek dan jangka lebih panjang. 


\section{Penutup}

Kurikulum dalam arti luas yaitu sebagai program pengajaran pada suatu jenjang pendidikan; sedangkan dalam arti sempit yaitu suatu mata pelajaran untuk beberapa jam pelajaran. Disain kurikulum harus memenuhi 2 syarat yaitu (1) kesesuaian antara kurikulum dengan tuntutan, kebutuhan, kondisi, dan perkembangan masyarakat; (2) kesesuaian antara komponen-komponen kurikulum yaitu isi sesuai dengan tujuan, proses sesuai dengan isi dan tujuan. Sumber-sumber pembuatan sebuah kurikulum terdiri dari ilmu, masyarakat, keabadian dan keilahian, pengetahuan, dan peserta didik. Pertimbanganpertimbangan yang mendasari pembuatan sebuah disain kurikulum adalah jangkauan (scope), rentetan (sequence), kesinambungan (continuity), integrasi, artikulasi, dan keseimbangan. Komponen kurikulum terdiri dari 4 (empat) elemen yaitu kompenen tujuan, kompenen materi ajar, komponen strategi, dan komponen evaluasi. Komponen tujuan berhubungan dengan arah atau hasil yang diharapkan sehingga segala proses pembelajaran difokuskan untuk mencapai tujuan tersebut. Ada 4 (empat) hirarki tujuan pendidikan di Indonesia yang saling terkait satu dengan yang lain yaitu Tujuan Pendidikan Nasional, Tujuan Institusional, Tujuan Kurikuler, dan Tujuan Pembelajaran Instruksional. Komponen Materi Ajar pada hakikatnya adalah isi kurikulum yang disusun dan dikembangkan berdasarkan prinsip-prinsip yang berlaku. Secara umum, isi kurikulum hendaklah memenuhi dimensi logika, etika, dan estetika. Isi kurikulum harus memenuhi prinsip sahih dan signifikan, relevan, seimbang, mencakup ragam tujuan, dan sesuai degan kemampuan dan pengalaman peserta didik. Komponen Strategi mempunyai peranan penting karena berhubungan dengan implementasi kurikulum. Komponen strategi meliputi pendekatan pembelajaran (pendekatan filsafati, pendekatan psikologi, dan pendekatan sistem), strategi pembelajaran, dan model pembelajaran. Komponen Evaluasi merupakan komponen yang digunakan untuk melihat efektivitas pencapaian tujuan. Prinsip-prinsip evaluasi kurikulum meliputi tujuan evaluasi, bersifat obyektif, bersifat komprehensif, kooperatif dan bertanggungjawab dalam perencanaan, efisien, dan berkesinambungan.

Setelah mempelajari komponen-komponen kurikulum dan peranannya, penulis member beberapa rekomendasi bagi para pembaca yang terlibat dalam dunia pendidikan, khususya bagi pendidik yang fokus dalam perencanaan, implementasi, dan evaluasi sebuah kurikulum di sekolah. Adapun rekomendasi kami adalah sebagai berikut: 
a. Seorang pendidik yang berkecimpung dalam kurikulum hendaklah mempelajari dasar-dasar filsafat, psikologi, ataupun sosial agar bisa melihat permasalahan secara kritis, sistematis, dan logis, sehingga bisa mencari suatu solusi yang maksimal.

b. Seorang berkecimpung dalam pembuatan kurikulum hendaklah mempelajari sumber-sumber disain kurikulum secara detail yaitu tentang ilmu, masyarakat, keabadian dan keilahian, pengetahuan, dan peserta didik.

c. Seorang berkecimpung dalam pembuatan kurikulum hendaklah mempertimbangkan tentang jangkauan (scope), rentetan (sequence), kesinambungan (continuity), integrasi, artikulasi, dan keseimbangan.

d. Secara khusus, seorang yang bertanggung jawab dalam pembuatan keputusan tentang kurikulum haruslah mempelajari dan memahami secara lengkap tentang komponen-kompenen kurikulum yaitu komponen tujuan, komponen materi ajar, komponen strategi, dan komponen evaluasi.

\section{References}

Bahm, Archie, J. 1980. What Is Science, Reprinted from my Axiology; The Science Of Values. 44-49, New Mexico: World Books.

Jujun S. Suriasumantri. 1982. Filsafah Ilmu: Sebuah Pengantar Populer. Jakarta: Sinar Harapan.

Ornstein, Allan C. dan Hunkins, Francis P. 1988. Curriculum, Foundations, Principles, and Issues. Needham Heights: Allyn \& Bacon.

Saridudin. (2021). Pengembangan Pendidikan Karakter Dalam Pembelajaran PAI Pada Sekolah Menengah. OSF Preprints, 1. https://doi.org/10.31219/osf.io/7p54a.

Saridudin, S. (2020). Pengembangan Kurikulum Pendidikan Diniyah Formal (PDF) Di Pesantren Ulya Zainul Hasan Probolinggo. EDUKASI: Jurnal Penelitian Pendidikan Agama Dan Keagamaan, 18(1), 84-99. http://dx.doi.org/10.32729/edukasi.v18i1.690

Tim Pengembang MKDP Kurikulum dan Pembelajaran Jurusan Kurikulum dan Teknologi Pendidikan Fak. Ilmu Pendidikan UPI. 2011. Kurikulum dan Pembelajaran. Jakarta: PT Rajagrafindo Persada.

Wibisono, S, Koento, dkk. 1997. Filsafat Ilmu Sebagai Dasar Pengembangan Ilmu Pengetahuan. Klaten: Intan Pariwara. 
Wibisono, S, Koento. 1984. FilsafatI lmu Pengetahuan dan Aktualitasnya dalam Upaya Pencapaian Perdamaian Dunia yang Kita Cita-Citakan. Yogyakarta: Fakultas Pasca Sarjana UGM.

Filsafat_Ilmu,http://members.tripod.com/aljawad/artike/filsafat_ilmu.htm.

http://www.scribd.com/doc/12448593/Filsafat-Ilmu-Sebagai-Landasan-pengembanganilmu-pengetahuan diakses tanggal 02 Januari 2021 pukul 10.35 WIB 